\title{
Histological Comparison of two Special Methods of Staining Melanin in Human Skin
}

\author{
Comparación Histológica de dos Métodos Especiales de Tinción de Melanina en Piel Humana
}

\author{
Munire Shataer'; Saimire Shataer²; Liao Libin'; Li Tian' \& Bai Shengbin ${ }^{1}$
}

SHATAER, M.; SHATAER, S.; LIBIN, L.; TIAN, L. \& SHENGBIN, B. Histological comparison of two special methods of staining melanin in human skin. Int. J. Morphol., 38(6):1535-1538, 2020.

SUMMARY: Human skin melanin was stained using the Fontana's silver nitrate method and Schmorl method. The results showed that, in the Fontana's silver nitrate method, melanin and silver-bound cells were black and other tissues were red. When stained using the Schmorl method, effects on melanin differed based on whether the nuclei were stained. When the nucleus was stained, melanin appeared blueblack or blue-green, and other tissue structures were purple. When the nucleus was not stained, melanin was orange and other structures were pink. Comparing the two staining methods, we concluded that Fontana's silver nitrate method takes a long time; in contrast, the Schmorl method showed two different types of results depending on whether the nucleus was stained, and it takes less time than Fontana staining, so we here consider the Schmorl method more suitable for special staining of melanin than Fontana's silver nitrate method.

KEY WORDS: Melanin; Fontana's Silver Nitrate Method; Schmorl Method.

\section{INTRODUCTION}

Melanin is a biological pigment. It is formed by a series of chemical reactions of tyrosine. It is produced by melanocytes and found in animals, plants, and microbes (Longo et al., 2017). Melanin in the human body is mainly distributed in the skin, hair, iris, and choroid. In the human body, the skin is divided into epidermis and dermis, and the epidermis is divided into a cuticle layer, transparent layer, granular layer, spinous layer, and basal layer from outside to the inside. Melanocytes are scattered between the basal cells of the epidermis and within the hair follicles (Fan et al., 2015). Although conventional H\&E staining stains the structure of the skin clearly, it fails to distinguish melanin from surrounding tissues. By contrast, the Fontana's silver nitrate method and the Schmorl method dye melanin different colors from surrounding tissues, which makes it easier to distinguish and observe.

\section{MATERIAL AND METHOD}

Fontana's silver nitrate method. The sections were dewaxed and washed thoroughly with distilled water.
They were placed in silver nitrate solution at room temperature for $18-48 \mathrm{~h}$ and then stored in a dark place. The sections were removed from storage and rinsed several times with distilled water, treated with a $0.2 \%$ gold chloride solution for $10 \mathrm{~min}$, and then washed with distilled water. They were fixed with $3 \%$ sodium thiosulfate for $2 \mathrm{~min}$ and rinsed with running water for 2 min. After counterstaining with $1 \%$ Nuclear Fast Red for 2-4 min, the samples were washed with tap water for $30 \mathrm{~s}$. Finally, they were dehydrated with ethanol, rendered transparent with xylene, and sealed with neutral gum.

Schmorl method. We dewaxed the sections using water. We used 1 part $3 \%$ ferric chloride or $25 \%$ ferrous sulfate and 1 part $1 \%$ potassium ferricyanide to prepare the solution. These were mixed and the dye was applied for $3 \mathrm{~min}$, until the slices were light green (when using $25 \%$ ferrous sulfate, the sample needed to be dyed for $30 \mathrm{~min}$ ). The samples were washed with water, then dehydrated with $95 \%$ and $100 \%$ alcohol, rendered transparent with xylene, and sealed with balsam. When it was not necessary to stain the nucleus, after dyeing with potassium ferricyanide and washing, we used 9 parts saturated picric acid and 1 part acid fuchsin to make a solution,

\footnotetext{
${ }^{1}$ Department of Histology and Embryology, Basic Medical College of Xinjiang Medical University, Ürümqi, Xinjiang, PR China.

${ }^{2}$ Department of Neurology,the Second Affiliated Hospital of Xinjiang Medical University, Ürümqi,Xinjiang,PR China.

FUNDING: This research was supported by grants from the University Research Program of Xinjiang (XJEDU2018Y027); Student Research Training Program of Xinjiang Medical University (CX2019060).
} 
and we dyed the samples for 3 to $5 \mathrm{~min}$. Finally, the samples were dehydrated with $95 \%$ and $100 \%$ alcohol, rendered transparent with xylene, and sealed with fragrant gum.

\section{RESULTS}

Fontana's silver nitrate method. The stratum corneum, the transparent layer, and the granular layer were all dyed pink, the spinous layer was pink, and the nuclei of the spinous cells were pink, but there were some black particles in the deep spinous cells. In addition, there were also scattered black particles between the basal cells. The dermis was lightly stained. Fontana's silver nitrate staining results showed that melanin was stained black and distributed between basal cells, and in the deep-layer spinous cells. The other tissue structures were stained pink (Fig.1B)

Schmorl method. When the nucleus was stained, the stratum corneum, transparent layer, and granular layer were all dyed purple, and the transparent layer was darker. The spinous layer was purple, and the nucleus of the spinous cells was also purple, but there were some blue-green particles in the deeplayer spinous cells, which were located close to the basal layer. Blue-green particles were also distributed between the basal cells. The dermis layer was light purple, without blue-green substance. In summary, the Schmorl method dyes melanin blue-black or blue-green and is distributed in the deep spinous cells and between the basal cells (Fig.1C).

When the nucleus was not stained, the stratum corneum, the transparent layer, the granular layer were pink, and the transparent layer was stained darker. The spinous layer was pink, and orange particles were visible in the spinous cells that were near the basal layer. Orange particles were also distributed between the basal cells, and the dermis layer was light pink without any orange particles. In summary, when the nucleus was not stained, the Schmorl method stained melanin orange, and the melanin was distributed in the deep spinous cells and between the basal cells (Fig. 1D) (Table I).
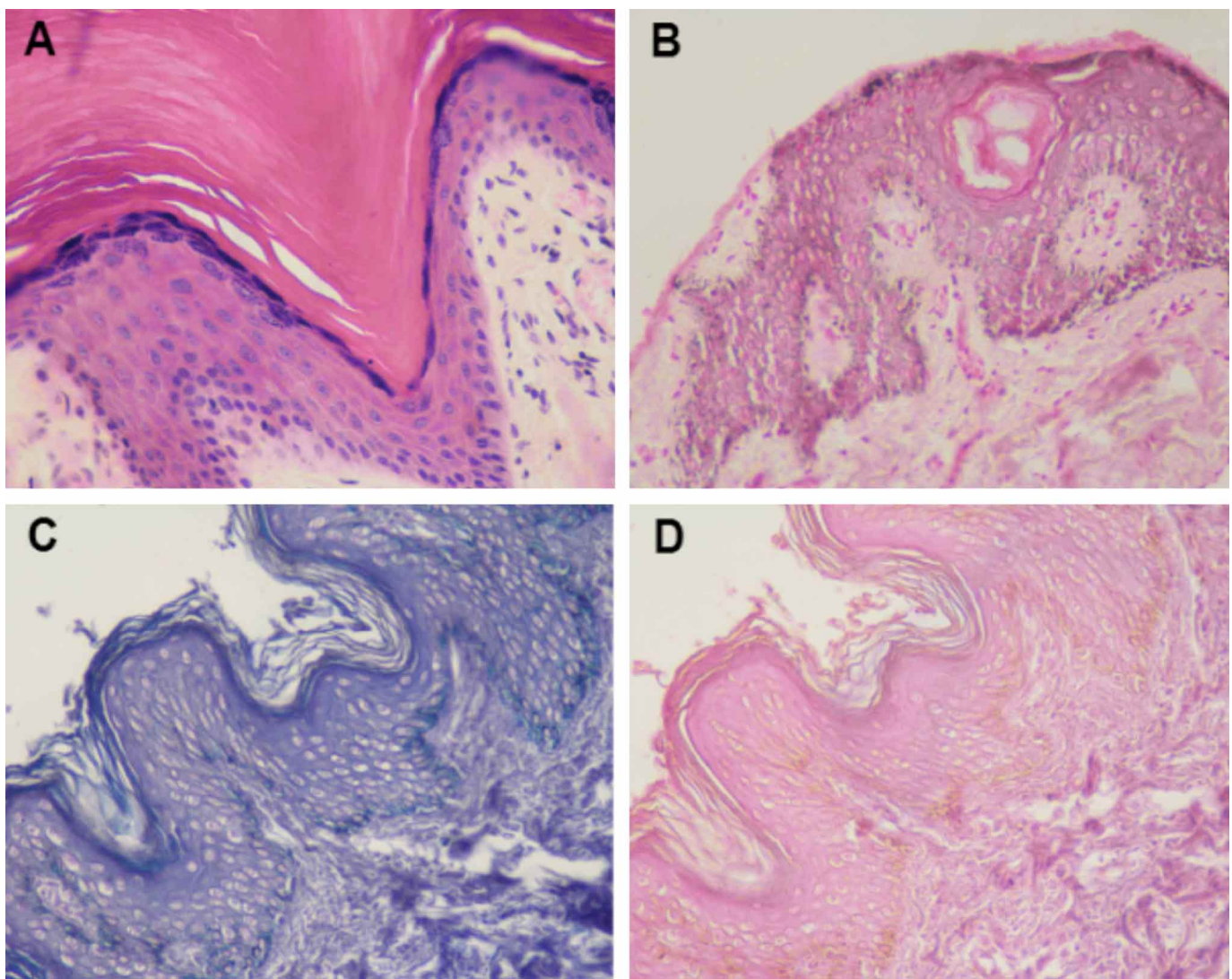

Fig.1.These images were seen under a light microscope. A shows the HE staining method. The epidermal layer from the outside to the inside is as follows: cuticle layer, transparent layer, granular layer, spinous layer, and basal layer $(\times 40)$. B shows Fontana's silver nitrate method. The melanin was black and scattered among the basal cells $(\times 40)$. C shows the Schmorl method with the nucleus stained. The melanin was blue-green and scattered among the basal cells $(\times 40)$. D shows the Schmorl method without staining of the nucleus. Melanin was orange and scattered among the basal cells $(\times 40)$. 
Table I. Comparison of the results of three staining methods.

\begin{tabular}{|c|c|c|c|c|c|}
\hline \multicolumn{6}{|c|}{ Comparison of the results of three staining methods } \\
\hline & & \multirow[t]{2}{*}{ HE } & \multirow{2}{*}{$\begin{array}{l}\text { Fontana's silver nitrate } \\
\text { method }\end{array}$} & \multicolumn{2}{|c|}{ Schmorl method } \\
\hline & & & & Stained nucleus & Unstained nucleus \\
\hline \multicolumn{6}{|l|}{ Epidermis } \\
\hline & Stratum comeum & Pink & Pink & Purple & Pink \\
\hline & Transparent layer & Red & Pink & Dark purple & Dark pink \\
\hline & Granular layer & Dark purple & Pink & Purple & Pink \\
\hline & Spinous layer & Light purple & Pink & Purple & Pink \\
\hline & Basal layer & Purple & Pink & Purple & Pink \\
\hline \multirow{4}{*}{$\begin{array}{c}\text { Dermis } \\
\text { Melanin }\end{array}$} & & Light pink & Light pink & Light purple & Light pink \\
\hline & & & & & \\
\hline & Color & - & Black & Blue-black or blue-green & Orange \\
\hline & Distribution & - & $\begin{array}{l}\text { In the deep spinous cells } \\
\text { and between the basal cells }\end{array}$ & $\begin{array}{l}\text { In the deep spinous cells } \\
\text { and between the basal cells }\end{array}$ & $\begin{array}{l}\text { In the deep spinous cells } \\
\text { and between the basal cells }\end{array}$ \\
\hline
\end{tabular}

\section{DISCUSSION}

Melanin is present in the integument of animals and determines the color of the skin, hair, and eyes. The melanin in the organism can resist ultraviolet radiation and scavenge free radicals. It is considered a barrier that the organism uses to protect itself (Eisenman \& Casadevall, 2012). When the content of melanin changes, pathological diseases can occur. When there is too much melanin, there is a risk of melanoma (Umek et al., 1991), and albinism can occur when melanin content is too low (Marçon \& Maia, 2002). The detection of melanin content is particularly important. Although conventional HE staining clearly shows the hierarchical structure of the skin, it cannot distinguish melanin from the tissue structure or from other pigment particles, nor can it determine melanin content.

Fontana's silver nitrate method stains melanin black and other tissues are red, so that melanin can be distinguished from surrounding tissues and can be detected and localized. Although Fan Hui's fast Fontana staining method (Fan et al., 2002) can stain melanin faster, it requires microwave radiation during the staining process, which is not easy to achieve under normal experimental conditions. In contrast, Fontana's silver nitrate method does not require excessive equipment support and can be completed in a common test environment. The process is easy and convenient, and the color sensitivity is strong. However, this method cannot distinguish the silver-phile cells that have the same ability to reduce silver nitrate as melanin.

When stained with the Schmorl method, the methods used to stain or not to stain the nucleus and the final results were quite different. When the nuclei were not stained, 9 parts saturated picric acid and 1 part fuchsin were used to prepare a solution, and the tissue was stained for 3 to $5 \mathrm{~min}$.
As a result, melanin was orange and other structures were pink. When the nuclei were stained, melanin was blue-black or blue-green, and other tissue structures were purple. Both methods were able to indicate melanin well. In Miaozhu's ferrous sulfate absorption method (Dong et al., 2006), melanin could only be dyed blue-green. The cell nucleus was not stained, and no melanin was stained orange. This is the advantage of Schmorl over the ferrous sulfate absorption method.

In summary, both Fontana's silver nitrate method and the Schmorl method showed that melanin was distributed between the basal cells of the human epidermis, which distinguishes the epidermal layer from the dermal layer. These two methods are relatively simple, have good dyeing effects, and do not require any specialized equipment. Fontana's silver nitrate method took a long time, requiring $18-48 \mathrm{~h}$ of treatment in silver nitrate solution. This is one of the disadvantages of Fontana staining relative to the Schmorl method. In contrast, the Schmorl method showed two different types of results depending on whether the nucleus was stained or not, and it took less time than Fontana's silver nitrate method, so it was more suitable for special staining of melanin than Fontana staining.

Hematoxylin and eosin staining (H\&E) is one of the most common methods of investigating the status of cells and tissues. However, after staining with HE, tissues are very difficult to use in further histological analysis because hematoxylin is difficult to remove from the sections due to the stability of the stain. In response to this situation, Ozawa \& Sakaue (2020) developed a decolorizing solution that could decolor the hematoxylin or iron hematoxylin stain from stained structures, including the nucleus, and the decolorized 
part could be stained again in another process, such as immunohistochemistry, without affecting the immunohistochemical results. This decolorizing solution can remove color from the archived old sections. According to the results given above, for archived rare pathological sections of albinism, melanoma, and other cases, decoloring the sections, and then treating them with Fontana's silver nitrate method, Schmorl method, or other new technologies and detection methods could provide vital information for the development of new treatment methods.

SHATAER, M.; SHATAER, S.; LIBIN, L.; TIAN, L. \& SHENGBIN, B. Comparación histológica de dos métodos especiales de tinción de melanina en piel humana. Int. J. Morphol., 38(6):1698-1701, 2020.

RESUMEN: La melanina de la piel humana se tiñó utilizando el método del nitrato de plata de Fontana y el método Schmorl. Los resultados mostraron que, en el método del nitrato de plata de Fontana, la melanina y las células unidas a plata eran negras y otros tejidos eran rojos. Cuando se tiñó con el método de Schmorl, los efectos sobre la melanina difirieron en función de si se tiñeron los núcleos. Cuando se tiñó el núcleo, la melanina apareció de color azul-negro o azul-verde, y otras estructuras de tejido fueron de color púrpura. Cuando el núcleo no estaba teñido, la melanina era naranja y otras estructuras eran rosadas. Al comparar los dos métodos de tinción, llegamos a la conclusión de que el método del nitrato de plata de Fontana lleva mucho tiempo; por el contrario, el método Schmorl mostró dos tipos diferentes de resultados dependiendo de si el núcleo estaba teñido, y lleva menos tiempo que la tinción de Fontana, por lo que aquí consideramos que el método Schmorl es más adecuado para la tinción especial de melanina que el método del nitrato de plata de Fontana.

PALABRAS CLAVE: Melanina; Método del nitrato de plata de Fontana; Método Schmorl.

\section{REFERENCES}

Dong, M. Z.; Xiao, P. \& Hong, X. Y. Comparative study on different stain methods for melanin in guinea pig skin. Environ. Occup. Med., 23(5):423-5, 2006.

Eisenman, H. C. \& Casadevall, A. Synthesis and assembly of fungal melanin. Appl. Microbiol. Biotechnol., 93(3):931-40, 2012.

Fan, H.; Li, B. Y. \& Zhao, H. Introduce a fast Fontana staining method. J. Shandong Med. Uni., 40(1):66, 2002.

Fan, Y. J.; Dai, H. Y. \& Lyu, C. Research about the model of pigmentation after autologous full-thickness skin transplantation on guinea pigs. Chin. J. Aesthet. Plast. Surg., 26(4):228-30, 2015.

Longo, D. L.; Stefania, R.; Aime, S. \& Oraevsky, A. Melanin-based contrast agents for biomedical optoacoustic imaging and theranostic applications. Int. J. Mol. Sci., 18(8):1719, 2017.

Marçon, C. R. \& Maia, M. Albinism: epidemiology, genetics, cutaneous characterization, psychosocial factors. An. Bras. Dermatol., 94(5):503$20,2019$.
Ozawa, A. \& Sakaue, M. New decolorization method produces more information from tissue sections stained with hematoxylin and eosin stain and masson-trichrome stain. Ann. Anat., 227:151431, 2020.

Umek, R. M.; Friedman, A. D. \& McKnight, S. L. CCAAT-enhancer binding protein: a component of a differentiation switch. Science, 251(4991):288-92, 1991.

Corresponding author:

Dr. Shengbin Bai

Department of Histology and Embryology

Basic Medical College of Xinjiang Medical University

Ürümqi, Xinjiang

CHINA

Email: bsbxx@126.com

Received: 04-05-2020

Accepted: 25-06-2020 